\title{
Spoken Language
}

National Cancer Institute

\section{Source}

National Cancer Institute. Spoken Language. NCI Thesaurus. Code C51277.

Language communicated by means of words or sounds uttered through the mouth. 